\title{
More on Normic Support and the Criminal Standard of Proof
}

\author{
Martin Smith
}

In this paper I respond to Marcello Di Bello's criticisms of the 'normic account' of the criminal standard of proof (Di Bello, 2019). In so doing, I further elaborate on what the normic account predicts about certain significant legal categories of evidence, including DNA and fingerprint evidence and eyewitness identifications.

\section{I. 'Beyond Reasonable Doubt'?}

According to one influential theory, the standard of proof for criminal trials should be interpreted in probabilistic terms. On this view, a proposition $\mathrm{P}$ is proved to the criminal standard just in case the probability of $P$, given the presented evidence, is above some high threshold - typically $90 \%$ or $95 \%$ (see, for instance, Cullison, 1969, section IIIA, McCauliff, 1982, Shauer and Zeckhauser, 1996, section III, Hedden and Colyvan, 2019). While this has an obvious appeal, the criminal standard of proof is closely associated, in legal doctrine, in jury instructions, and in the popular imagination, with the idea of proof 'beyond reasonable doubt $^{\prime 1}$. And this phrase doesn't obviously indicate a probability threshold, which would be more naturally conveyed with the words 'to a high probability' or some such. In fact, the idea that something has been proved 'beyond reasonable doubt' suggests a rather different way of thinking about uncertainty - that doubts can be divided into two categories, the reasonable and the unreasonable, and that all doubts of the former kind have been answered. Some theorists insist that the 'beyond reasonable doubt' phrasing is deeply unclear - and no help when it comes to understanding the criminal standard of proof (Laudan, 2006, chap. 2). While I agree that it would be a mistake to fixate on these words too closely, their meaning is hardly opaque - it is natural, in many contexts, to distinguish between doubts that are serious and demand attention and doubts that are speculative or frivolous.

In 'When does evidence suffice for conviction?' (2018) I defended the claim that the criminal standard of proof should be interpreted, in part, in terms of a relation I term normic support. A body of evidence E normically supports a proposition $\mathrm{P}$ just in case the situation in which $E$ is true and $P$ is false is less normal, in the sense of requiring more explanation, than the situation in which $\mathrm{E}$ and $\mathrm{P}$ are both true. In short, a body of evidence $\mathrm{E}$ normically supports a proposition $\mathrm{P}$ just in case it generates the need for special explanation in the event that $\mathrm{P}$ is false. Suppose I'm shopping for furniture that will fit the colour scheme in my lounge and my attention is caught by a sofa that appears to me to be red. If the sofa were not red, even

\footnotetext{
${ }^{1}$ The 'beyond reasonable doubt' phrasing has recently been dropped from criminal jury instructions in England, with the Crown Court Compendium recommending that jurors be instructed to convict if, having considered all the relevant evidence, they are 'sure that the defendant is guilty' (see https://www.judiciary.uk/wpcontent/uploads/2018/06/crown-court-compendium-pt1-jury-and-trial-management-and-summing-up-june2018-1.pdf, section 5.1). The Compendium goes on to clarify, however, that this means the same thing as proof 'beyond reasonable doubt' and the jury should be told as much if the question is raised (sections 5.3 and 5.7). The beyond reasonable doubt wording is still used in criminal jury instructions throughout most common law jurisdictions. In 1970, the US Supreme Court ruled that the constitutional right to due process requires that juries in criminal trials be instructed that proof beyond reasonable doubt is the standard for conviction (In re Winship 397 U.S. 358 (1970), at 361-365).
} 
though it appeared red, there would have to be some explanation as to how this could be perhaps the sofa is bathed in red light, perhaps I am having a colour hallucination etc. Thus my evidence provides normic support for the proposition that the sofa is red.

While it would be possible for me to doubt that the sofa is really red, this doubt would have to be supplemented by some kind of narrative - perhaps along the lines just suggested - in order to make it intelligible. It can't be that the sofa appears to be red, but isn't red end of story. There has to be something more to the story here, and it is incumbent upon anyone who takes this possibility seriously to provide this 'something more'. Given my evidence, doubts about the redness of the sofa require active narrative construction, while doubts about whether, say, the sofa is comfortable could be completely passive and wouldn't need any accompanying narrative. The proposition that the sofa is comfortable is not normically supported by any evidence that I yet possess.

Turning to a legal example, suppose a defendant is on trial for shoplifting, on the grounds that several unpurchased items were recovered from his bag as he attempted to leave a shopping centre. This evidence normically supports the defendant's guilt. If he were innocent, there would have to be some special explanation as to how the items in question came to be in his possession - perhaps they were planted in an attempt to frame him, perhaps they fell unnoticed into his open bag when he accidentally bumped into a shelf etc. Whatever the case, it can't 'just so happen' that the items were in his bag and there is nothing more to say. While this evidence does leave room for doubts about the defendant's guilt, such doubts would need to be woven into some kind of narrative and, without any evidence to support this narrative, they are apt to seem unreasonable.

If evidence $E$ normically supports proposition $P$, then $E$ closes off the possibility of purely passive doubts about $P$ - any doubts about $P$, in light of $E$, would require a supplementary narrative of some kind. If normic support is necessary for meeting the criminal standard of proof then all passive doubts will, in effect, be reasonable doubts ${ }^{2}$. This view which I will refer to as the 'normic account' - will be my focus here. Returning to the above case, if the defendant is unable to provide any explanation as to how the items wound up in his bag, then the normic account is consistent with the claim that his guilt has been proved to the criminal standard.

One advantage of the normic account is that it offers a satisfying treatment of cases involving pure statistical evidence, such as the following, due to Nesson (1979): Suppose 100 prisoners are exercising in a yard when 99 of them assault and kill a prison guard in what

\footnotetext{
${ }^{2}$ Other conditions on the criminal standard of proof can be thought of as further expanding the range of 'reasonable' doubts. According to one possible 'hybrid' view that I have discussed previously, a proposition P is proved to the criminal standard just in case it is normically supported by the evidence and its probability, given the evidence, is above a high threshold $\mathrm{t}$ (Smith, 2018, pp1210-1211). In this case, a reasonable doubt would be either a passive doubt or an active doubt that is sufficiently likely to obtain - that has a probability of at least $1-t$. If one adopted a purely probabilistic interpretation of the criminal standard of proof, then the reasonable doubts would be all and only those that were sufficiently likely to obtain, and any doubt that was too unlikely passive or not - would be unreasonable. Even the probabilistic approach can, then, be squared with the words 'beyond reasonable doubt' - the point made above is merely that natural language supplies far more direct ways of indicating a high probability threshold.
} 
appears to be a pre-planned attack. The 100th prisoner seems shocked by the attack and plays no part, but later intermingles with the others. Suppose that one of the prisoners in the yard is selected at random and put on trial for the guard's murder, with the prosecution presenting the evidence, accepted by all parties, that 99 of the 100 prisoners in the yard participated in the attack.

The evidence in this case makes it $99 \%$ likely that the prisoner is guilty. If the criminal standard of proof is to be interpreted exclusively in probabilistic terms, it's clear that he ought to be convicted - and yet many people find themselves reluctant to base a conviction upon evidence of this kind. In spite of its probabilistic strength, the evidence presented in this case does not provide normic support for the prisoner's guilt. Even though 99 of the prisoners in the yard participated in the attack, it could be that the prisoner on trial just happens to be the one who was not involved, with no further explanation needed. Doubts about the prisoner's involvement require no narrative in order to make them intelligible. According to the normic account, the criminal standard of proof is not met and, in the absence of any further evidence, the prisoner should be acquitted of the guard's murder ${ }^{3}$.

The normic account will predict, more generally, that pure statistical evidence of this kind is never enough, on its own, to meet the criminal standard of proof. While many would welcome this prediction, the normic account has other consequences which may seem less appealing. One of these - the starting point for Di Bello's criticism - concerns what is sometimes called 'cold-hit' DNA evidence. It is to this that I turn next.

\section{DNA Evidence}

A DNA profile is built by testing a range of loci in the genome. DNA evidence in criminal prosecution typically takes the form of a reported match, at all tested loci, between the DNA profile of a defendant and a DNA sample recovered from a crime scene and thought to belong to the offender. In most jurisdictions, this evidence would be presented in court by an expert witness who will also provide the fact-finder with a 'random match' probability - the (typically minute) probability that a randomly selected member of the population would match the sample 4 . In a case of 'confirmatory' DNA evidence, the crime scene sample is matched to the

\footnotetext{
${ }^{3}$ For some alternative treatments of pure statistical evidence cases see, for instance, Tribe (1971), Cohen (1977), Nesson (1979), Thomson (1986), Enoch, Fisher and Spectre (2012), Stein (2005, chap. 3), Nance (2016, chap. 3), Gardiner (2019), Littlejohn (2020), Moss (forthcoming).

${ }^{4}$ The loci tested in DNA profiling, sometimes referred to as short tandem repeat (STR) loci, feature multiple repetitions of a short sequence of base pairs. These loci are known to exhibit a very high level of variability in the human population - such that the frequency of a particular number of repeats at a given locus is relatively low - and to be mutually independent - such that the frequency of a particular number of repeats at a given locus is unaffected by the number of repeats at the other loci. As a result, a random match probability for a DNA profile can, roughly speaking, be calculated by multiplying the frequencies of the variants at each locus (see Saks and Koehler, 2005, Roth, 2010, section IA). The number of loci tested will be determined by the method used and by the quality of the sample but may, in the best cases, be sufficient to generate a random match probability of one in trillions. For degraded samples, which are common, the random match probabilities may be many orders of magnitude higher. It is also worth noting that there are several acknowledged cases of actual DNA random matches in criminal prosecution (for discussion see Roth, 2010, section IA).
} 
profile of a person who has already been singled out as a suspect. In a case of cold-hit DNA evidence, the sample is run against a DNA database yielding a match (a 'cold-hit') with the profile of a person who has no other known connection to the crime.

While further evidence may emerge against a person initially identified via a DNA coldhit, it is becoming increasingly common for people to be charged, prosecuted and convicted without additional evidence - when the case against them rests largely, or solely, on the reported cold-hit (see Roth, 2010, section IB) ${ }^{5}$. I have argued that the possibility of a random match means that cold-hit DNA evidence cannot provide normic support for a defendant's guilt (Smith, 2018, section 4). If a defendant is innocent, in spite of the cold-hit DNA evidence against them, there may be an explanation for this - perhaps their DNA was planted at the crime scene, or the sample was contaminated prior to testing, or perhaps samples were mislabelled or confused in the laboratory, or an error was made in the testing procedure itself etc. But even if nothing like this occurred, it could still be the case that the defendant had no involvement in the crime and their profile matched the crime scene sample by pure chance. While doubts about the defendant's guilt could involve a narrative of some kind, the evidence also leaves scope for purely passive doubts.

If the normic account is correct, then a reported DNA cold-hit cannot, on its own, prove a defendant's guilt to the criminal standard. Di Bello portrays this as a radical consequence of my view, as have others (Levanon, 2019, pp272, Krauss, forthcoming, section $I I A, 1)$. While there is considerable enthusiasm for cold-hit DNA convictions in some quarters, they have long been a source of controversy, and some theorists have argued that a conviction should never be based solely on evidence of this kind (McCartney, 2006, pp100101, 145, Sangero and Halpert, 2007, section IV). In the United States, the first report of the National Research Council on DNA technology in forensic science, released in 1992, recommended that DNA cold-hits be used only as a way of identifying suspects and not as incriminating evidence in their own right - though this was overturned in the second report released four years later (for critical discussion of the recommendations of this report see Sangero and Halpert, 2007, section IVC) ${ }^{6}$.

\footnotetext{
${ }^{5}$ To say that people have been convicted solely on the basis of cold-hit DNA evidence may be somewhat misleading. In one sense there is always additional evidence - evidence to the effect that a crime took place, evidence to the effect that it was the offender's DNA that was found at the crime scene etc. But there are cases in which a reported DNA cold-hit is the only evidence which speaks to the question of the offender's identity. A 'cold-hit DNA conviction' might be defined as any conviction in which cold-hit DNA evidence is the primary or sole evidence connecting the defendant to the crime. The rise in cold-hit DNA convictions is linked to a number of other mutually reinforcing trends, such as the growth of DNA databases and the expansion of police powers to extract and store DNA profiles without consent (see Redmanyne, 1998, McCartney, 2006, chap. 4, Cole and Lynch, 2006, pp45-50). These topics are beyond the scope of the present paper.

${ }^{6}$ One might simply insist that, when there is cold-hit DNA evidence against a defendant, it would be absurd to acquit, given that the probability of innocence is so low. On one level, this claim is simply question-begging prison yard-type scenarios show that a very low probability of innocence is not enough to make a conviction legitimate. But we might also challenge the supposition on which this claim is based - that the probability of innocence really is 'so low' in cases involving cold-hit DNA evidence. It is true that, in some cases, the random match probability may be miniscule, but this does not represent the probability that the defendant is innocent, in spite of a certain tendency amongst judges, lawyers and jurors to interpret it in this way - what is sometimes called the 'prosecutor's fallacy' (see Sangero and Halpert, 2007, Roth, 2010, section II). We can derive, from a
} 
It is important to note that, if cold-hit DNA evidence is supplemented by incriminating evidence of other kinds, then a defendant's guilt may well be normically supported by the total evidence presented. Suppose, for instance, that an individual who is found through a DNA database search then lies to the police about their whereabouts, at the time the crime was committed. If the lie is exposed, and this evidence is admitted in a subsequent criminal trial, then it clearly generates the need for an explanation in the event that the individual is innocent. While the DNA cold-hit leaves open the possibility of purely passive doubts about the defendant's guilt, the additional evidence closes this possibility off - any doubts would now require a narrative of some kind. If no plausible narrative is provided by the defence, then the defendant's guilt is normicaly supported. The normic account allows, in general, that cold-hit DNA evidence can be part of a successful prosecution case ${ }^{7}$ - but it cannot be the entirety of such a case.

Whatever one thinks of the legitimacy of pure cold-hit DNA convictions, according to Di Bello, the blocking of such convictions is indicative of a more general problem for the normic account. Di Bello argues that, when we look closely at the epistemological structure of cold-hit DNA evidence, we see that this structure is common to many kinds of evidence, including fingerprint evidence and, most significantly, eyewitness identifications. As a result, if a defendant's guilt cannot be normically supported by cold-hit DNA evidence, then neither can it be normically supported by fingerprint evidence or by an eyewitness identification.

According to Di Bello, DNA evidence, fingerprint evidence and eyewitness identifications all rest, ultimately, upon a match between a trait allegedly possessed by the perpetrator of a crime and a trait allegedly possessed by the defendant in a criminal trial. The trait in question may be a DNA profile or a fingerprint ridge pattern or it may comprise a set of observable characteristics. Whatever the trait, though, it will never be uniquely identifying in which case, one might suppose, there is always a possibility that the match is random, and the defendant possesses the trait by pure chance. If the possibility of a random match prevents cold-hit DNA evidence from normically supporting a defendant's guilt, then it should also prevent fingerprint evidence or eyewitness identifications from normically supporting a

random match probability, a kind of probability of innocence, using an estimate of the size of the pool of potential culprits - but even this figure, which will be significantly higher than the random match probability, is conditional upon there being no laboratory error, no cross-contamination, no deliberate framing etc. While very bold claims have been made about the probative force of cold-hit DNA evidence (see, for instance, Cole and Lynch, 2006, pp51), the final probability of innocence, given a reported DNA cold-hit, is a matter of some speculation. I hope to pursue these issues elsewhere.

${ }^{7}$ Depending on what other conditions are required for the criminal standard of proof, cold-hit DNA evidence could yet play a crucial role in ensuring that these conditions are met. Consider, for instance, the 'hybrid' account, mentioned in $\mathrm{n} 2$, on which a defendant's guilt is proved to the criminal standard just in case it is normically supported by the evidence and made highly probable by the evidence. Returning to the above example, the mere fact that a defendant lied about their whereabouts when questioned by the police plausibly would not prove guilt to the criminal standard, so construed. Even if the defendant provides no explanation for the deception, one might think that the likelihood of there nevertheless being some innocent explanation is too high for the standard to be satisfied. In this case, the cold-hit DNA evidence could make a decisive difference the probability that the defendant is innocent in spite of the fabricated alibi and the reported match will presumably be sufficiently low. 
defendant's guilt. In this case, the normic account would block convictions based upon 'traitmatching' evidence of any of these kinds - even though, between them, they would seem to exhaust much of the evidence used in criminal prosecution. At the very least, the normic account would end up being a highly revisionary theory - contrary to the way in which I have presented it.

Di Bello suggests a possible way of modifying the normic account in order to allow cold-hit DNA convictions and avoid this problem (Di Bello, 2019, section 7). Di Bello argues that the normic account, so modified, could retain many of its advantages, particularly regarding cases of pure statistical evidence, such as the prison yard. I think that Di Bello's proposal is well worth exploring - and there may be further ways of weakening the normic account so as to deliver this result ${ }^{8}$. For what follows, though, I will stand by the original, unmodified normic account and attempt to tackle this problem 'head on', arguing that the account is more discriminating than Di Bello claims.

\section{Fingerprint Evidence and Eyewitness Identification}

I begin with fingerprint evidence - but my discussion here will be relatively brief. Fingerprint comparisons are typically carried out by one or more experts, guided by strict criteria for reporting a match. Fingerprint evidence in criminal prosecution typically takes the form of a reported match between a defendant's print and a print that is believed to have been left at a crime scene by the perpetrator. Like DNA evidence, fingerprint evidence can be either 'confirmatory', when a crime scene print is matched to the print of an existing suspect, or 'cold-hit', when the match is found via a database trawl.

\footnotetext{
${ }^{8}$ Di Bello proposes that the notion of normic support be relativised to a background body of information, and suggests that a random match be reconceived as a possible explanation as to how a defendant could be innocent in spite of the existence of cold-hit DNA evidence against them (albeit an explanation of a very different kind to laboratory error, cross contamination, deliberate framing etc.). Another option, which may bear some relation to Di Bello's proposal, is to make use of the notion of approximate or 'for all intents and purposes' normic support, introduced in Smith (2016, pp67-68). Say that evidence E provides approximate normic support for a proposition $\mathrm{P}$ just in case it is highly probable that there would be some special explanation in the event that $\mathrm{E}$ is true and $P$ is false. Arguably, cold-hit DNA evidence does provide approximate normic support for a defendant's guilt - if the defendant turns out to be innocent, it is far more likely that this will be due to laboratory error, cross contamination, deliberate framing etc. than the result of a random match (Koehler, Chia and Lindsey, 1995, Sangero and Halpert, 2007, section IVB). In the prison yard case, however, the defendant's guilt is not even approximately normically supported by the statistical evidence - if the defendant turns out to be innocent, this will be because he happens to be the one prisoner who didn't take part in the attack. If we replaced the notion of normic support with the notion of approximate normic support, the normic account would allow for cold-hit DNA convictions, while continuing to block convictions based upon prison yard-type statistical evidence.

It is also important to note that there are alternative accounts that appear capable of separating prison yard-type cases from cases involving cold-hit DNA evidence - and capable of blocking conviction in the former cases while allowing it in the latter (see for instance Enoch, Fisher and Spectre, 2012, n38, Enoch and Fisher, 2015, part III). While I think it is very worthwhile to investigate this combination of predictions, and the ways in which it could potentially be rationalised, I won't pursue this topic further here.
} 
I grant that there is no significant epistemological difference between cold-hit DNA evidence and cold-hit fingerprint evidence ${ }^{9}$. There are differences, however, in the way that these two kinds of forensic evidence are conventionally treated in criminal trials. There is a certain folklore to the effect that human fingerprints are unique, and the presentation of fingerprint evidence in court tends not to be accompanied by a random match probability or even an acknowledgement of the possibility of a random match (Saks and Koehler, 2005, McCartney, 2006, pp82-88, Sangero and Halpert, 2007, section IIIA). There is no scientific consensus, however, on whether human fingerprints are unique and, even if they are, that is not to say that a human expert will be capable, even in principle, of distinguishing the fingerprints of any two people $\mathrm{e}^{10}$.

In fact, random fingerprint matches do occur. In 2004, Spanish police found a fingerprint on a bag of explosives connected to the Madrid bombings. After a database search, the print was matched to that of Brandon Mayfield, a lawyer working in Oregon, with four FBI fingerprint experts verifying the match. Mayfield was detained for two weeks and only released when Spanish police found another suspect whose prints matched those on the bag (for discussion, see Cole and Lynch, 2006, pp49, Sangero and Halpert, 2007, section IIIB) ${ }^{11}$.

While I accept that Di Bello is correct about fingerprint evidence, I will argue that he is largely incorrect about eyewitness identifications. The first thing to note is that eyewitness identifications represent a far more heterogeneous category than either DNA or fingerprint matches. While DNA and fingerprint matches are always arrived at via a circumscribed set of procedures, eyewitness identifications can have very different bases, can be accompanied by very different kinds of collateral information, and can be provided by eyewitnesses with very different connections to the alleged offender. It would, in a way, be surprising if all instances of eyewitness identification could be made to fit the same epistemic mould. On close scrutiny, I think they cannot.

\footnotetext{
${ }^{9}$ Much the same could I suspect be said about forensic evidence that involves matches of other kinds handwriting, clothing fibres, voice patterns, bite marks, shoeprints etc. - but I won't consider this further here.

${ }^{10}$ Fingerprint classification is based upon three general ridge patterns - 'loop', 'whorl' and 'arch' - each of which can be broken down into several subtypes. When comparing two fingerprints, experts will focus on 'minutiae' - points at which a ridge terminates or bifurcates, with a reported match requiring the detection of a minimum number of shared minutiae, and no minutiae that are not shared (though the precise criteria for declaring a match vary from jurisdiction to jurisdiction - see McCartney, 2006, pp88-92, Evett and Williams, 2015). There have been occasional, somewhat informal, attempts to calculate random match probabilities for fingerprint evidence based upon the estimated frequencies of various minutiae (Evett and Williams, 2015, pp565-566).

${ }^{11}$ One might argue that this isn't in fact a case of a random match but, rather, a case in which the experts made an error when comparing the prints. (Spanish authorities did in fact voice concerns about the initial reported match.) Admittedly, the role of subjective expert judgment in fingerprint matching can make it difficult to disentangle 'practitioner' errors and 'method' errors (see Saks and Koehler, 2005, pp894). This may leave an opening for those who wish to argue that all errors are practitioner errors and the method does not in fact allow for random matches at all - but I won't explore this further here. In addition to the Brandon Mayfield incident, see also the case of Shirley McKie, which triggered a public inquiry into the use of fingerprint evidence in Scotland:

https://www.webarchive.org.uk/wayback/archive/20150428160106/http:/www.thefingerprintinquiryscotland .org.uk/inquiry/files/TheFingerprintInquiryReport High res.pdf
} 
Suppose a defendant is on trial for assault and the prosecution case rests upon the testimony of an eyewitness who identifies him as the culprit. Consider two contrasting cases. In the first case, the eyewitness is a bystander who had a brief, unimpeded view of the assailant and is able to give a description - say, 'Caucasian male of medium height and slim build with straight, shoulder-length, brown hair and a thin moustache...'. This description fits the defendant and forms the full basis of her identification. In the second case, the eyewitness offers no description - but is the defendant's sister, who happened to be having dinner with him when an altercation broke out with another diner.

These both count as 'eyewitness identifications' - and yet there are significant differences between them (see Thompson, 2008, pp1541, Davidson and Ferguson, 2014, section (a)). In the second case, if we accept that the assault really occurred, and accept that the eyewitness - the defendant's sister - is testifying honestly and sincerely, then there is no serious question as to whether she has correctly identified the assailant. While one could in principle have doubts about this, without evidence to back them up, such doubts would clearly be unreasonable. In the first case, however, even if one puts aside the possibility that the eyewitness is lying, one could clearly have reasonable doubts about her identification.

When Di Bello sets out his model of the epistemology of eyewitness identification, it seems to be the first kind of case that he has in mind. In this case, the identification is based upon a description which could be satisfied by a random member of the population. So it is with any 'template' description which simply supplies values for a series of demographic variables. When it comes to the second case, however, Di Bello's model is a less natural fit. When the eyewitness judges that she was having dinner with her brother at the time he assaulted another diner she is of course fallible - and, thus, we might conceive of her judgment as based upon inconclusive evidence of some kind. But she was not merely 'observing' her presumed brother - she was interacting with him, conversing, sharing a meal, perhaps they travelled together to the restaurant or met at a pre-arranged time etc. Her judgment that this really was her brother is not based on some 'trait' that could be shared by a random member of the population - this would completely misrepresent its epistemological structure. The evidence in this case is not best thought of as 'trait-matching' evidence at all - it works in a completely different way.

The evidence in the former case does not normically support the defendant's guilt. If the defendant were innocent there may be some explanation for this - the eyewitness is lying or has a false memory etc. - but, given its basis, the identification could also be wrong by pure chance, leaving room for passive doubts about the defendant's guilt. Furthermore, given the basis of this testimony, a fact-finder could well argue that the identification is unwarrantedthe most the eyewitness can legitimately claim is that the defendant 'looks like' or 'resembles' the offender. The evidence in the second case, however, does normically support the defendant's guilt. If the defendant is innocent, it could be that the eyewitness is lying or suffering a delusion, or an imposter was impersonating her brother etc., but it could not be the case that the identification is mistaken by pure chance, meaning that any doubts about the defendant's guilt would have to be active - embedded within a broader narrative. 
While the normic account would prevent conviction in the former case, it would not do so in the latter. This already serves to show that the account, contrary to what Di Bello claims, does not predict that an eyewitness identification can never prove guilt to the criminal standard. There are many cases in which an eyewitness is not merely a passive observer, but has a prior connection to the defendant. Sometimes an eyewitness has a close relationship with the defendant and was interacting with them at the time the crime took place - as in the example described above. Sometimes an eyewitness is an accomplice, who played a role in the alleged crime. Sometimes an eyewitness is the victim of the alleged crime and is testifying against a person who is well known to them. These are all eyewitness identifications of the second type - and the normic account will permit (though will not require) conviction in such cases.

While identifications of the second type are common in criminal trials, identifications of the first type, though they may be used as a way of identifying potential suspects, would not usually be put forward as sufficient grounds for conviction. People v Collins [68 Cal 2d 319 (1968)] is, however, one well known case in which the prosecution did use a strategy of this kind. The case involved an eyewitness to a robbery, who testified that it was committed by a white female of ordinary build with a blonde ponytail who was picked up in a yellow car driven by a black male with a beard and moustache. The defendants - Janet and Malcolm Collins - were a wife and husband who owned a yellow car, and who met these respective descriptions. While the eyewitness was prepared to identify Malcolm Collins, his identification was effectively impeached as a result of an earlier admission of uncertainty, and the prosecution was left solely with the descriptions that he had supplied. In order to strengthen their flagging case, the prosecution called an expert witness - a college mathematics instructor - who estimated that the probability of a randomly selected couple having all of the characteristics in question was 1 in 12 million. The defendants were convicted by a jury, but the conviction was reversed on appeal. While the appeal court was highly critical of the expert testimony - which appeared to be based on pure speculation ${ }^{12}-$ this was not the only reason given for the reversal. Importantly, the court found that, even if the 1 in 12 million figure had been supported by appropriate evidence, this would still have been insufficient to prove the defendants' guilt beyond reasonable doubt - a judgment that would be borne out by the normic account (amongst other interpretations of the criminal standard of proof) ${ }^{13}$.

\footnotetext{
12 The expert witness estimated the frequencies of various 'factors' in the population - of black males with beards, of males with moustaches, of white females with blonde hair, of white females with ponytails, of yellow cars and of interracial couples - and arrived at the 1 in 12 million figure by multiplying these frequencies together. Not only were the estimates themselves without foundation, but the use of the multiplication rule for determining a joint probability presupposes that the factors are independent - which some, at least, are clearly not (for discussion, see Tribe, 1971, pp1334-1337)

13 The court noted that the case also involved an egregious instance of the prosecutor's fallacy, in that the random match probability of 1 in 12 million was presented, and apparently accepted by the jury, as representing the probability of innocence. In an appendix to its decision the court argued that, even if one accepted that the eyewitness report was accurate, and accepted the 1 in 12 million random match probability, given a reasonable estimate of the number of couples who could have potentially committed the crime, the probability that this set includes at least one other couple possessing all of the characteristics in question may be in the region of $40 \%$
} 
The normic account predicts that a defendant should never be convicted solely on the grounds that they meet a reported description of the offender's appearance. Even if the description is highly specific, if it simply fills in values for a series of standard variables, and could apply to a randomly selected member of the population, then the defendant's guilt will not be normically supported. This is one sense in which the normic account predicts that an eyewitness identification may be insufficient for a conviction - but this prediction is not at odds with any established legal practice.

I turn finally to those eyewitness identifications that don't fit into either of the above categories; cases in which an eyewitness has no prior connection to the defendant, but who doesn't offer a description as the full basis of their identification - cases in which an eyewitness simply claims to recognise the defendant as the person who committed the crime. This is a common refrain for an eyewitness, and for good reason - if pressed to articulate how it is that we recognise a particular person, most of us would struggle to do so. While we might mention certain salient characteristics, we would be loath to accept that the basis of our recognition could be exhausted by any characteristics we can list, let alone by a template description of the kinds considered earlier ${ }^{14}$. In these cases of eyewitness identification, the fact-finder may learn more about the circumstances under which the crime was witnessed, may learn that the eyewitness was able to select the defendant from an identity parade ${ }^{15}$, and may even learn more about the kinds of factors that can affect eyewitness reliability but the fact-finder will not have access to the basis on which the testimony has been offered.

The position that the fact-finder is in, when confronted with an eyewitness identification of this kind, is similar to the position that we are all in with respect to much of the testimony that we receive in our daily lives. For much of the testimony that we encounter,

(at 333-334). As a result, even on a purely probabilistic interpretation of the criminal standard of proof, this evidence would arguably fall short.

If, however, the prosecution had managed to provide a principled random match probability that was much lower, and that translated into a genuinely low probability of innocence, then a proponent of the probabilistic interpretation would, all else equal, have no further objections to conviction. On the normic account, however, the prosecution case would still fail to prove guilt beyond reasonable doubt. From the text of the decision, it is unclear whether the court would be sympathetic to this further conclusion - though some of the comments strongly suggest that the evidence presented by the prosecution was of the wrong kind, and not merely of insufficient strength: 'Quite apart from our foregoing objections to the specific technique employed by the prosecution to estimate the probability in question, we think that the entire enterprise upon which the prosecution embarked, and which was directed to the objective of measuring the likelihood of a random couple possessing the characteristics allegedly distinguishing the robbers, was gravely misguided' (at 329). '...no mathematical equation can prove beyond a reasonable doubt (1) that the guilty couple in fact possessed the characteristics described by the People's witnesses, or even (2) that only one couple possessing those distinctive characteristics could be found in the entire Los Angeles area' (at 330).

${ }^{14}$ In order to express a proposition that fully conveys the basis on which I recognise someone, it may be necessary to make use of a perceptual demonstrative - they look like that, while indicating a photo or a portrait or the person themselves. Any attempt to give a context independent description is liable to fall short - to be satisfied by other individuals whom I could nevertheless distinguish.

${ }^{15}$ Requiring an eyewitness to select a suspect from an identity parade is one common procedure intended to guard against the possibility that an identification is based on nothing more than a template description, consisting of a series of standard descriptors. Identity parades are not always used however and, in some cases, are not fit for purpose (see Loftus, 1996, chap. 7, Wells et al., 1998). 
we won't have access to the reasons or grounds that lie behind it. If we do have such access, then we can scrutinise these grounds for ourselves, and the testimony can effectively be put to one side. But testimony is not usually dispensible in this way. In most cases, the question of whether or not to accept a piece of testimony is primarily a matter of trust - of whether we are willing to trust the testifier with respect to the matter at hand.

Some theorists have argued that deciding whether to accept testimony in favour of a proposition $\mathrm{P}$ is, in general, a very different sort of activity to evaluating evidence that bears upon P (see, for instance, Hinchman, 2005, Moran, 2018, partic. chap 2, Marušić, 2015, chap. 7). Whether or not this is so, in most cases of testimony the potential for evidence evaluation is strictly limited. The primary evidence that one has is simply the fact that the testimony has been offered. While one may have background evidence - about the testifier, or about the content of the testimony - that bears on how it is received, there is no evidence that can be substituted for the testimony itself.

Unadorned testimony is in fact perfectly capable of supplying normic support for its content. If a person testifies to a proposition $\mathrm{P}$, then this will generate a need for explanation in the event that $P$ is false. There are three basic forms that such an explanation can take: First, it may be that the testifier is being insincere or deceptive. Second, it may be that the testifier is affected by disobliging environmental conditions or cognitive malfunction. Third, it may be that the testimony is based upon insufficient evidence - evidence that could be combined with P's falsity without further explanation being needed. If I receive testimony in favour of $P$, then any doubts about $P$ would need to find a place within a narrative that proceeds along one of these lines. If I have no evidence for such a narrative, and no independent evidence against $P$, then $P$ will be normically supported ${ }^{16}$.

What goes for testimony in general goes for eyewitness identifications. If an eyewitness identifies a defendant as the one who committed a crime then, in the event that the defendant is innocent, an explanation is needed. If cross examination reveals that, say, the eyewitness has a strong motive to lie or had an obstructed view, or misremembered many significant details of the crime, then this need for explanation would be removed. And so it is if the identification is exposed as resting solely upon characteristics that could be shared by a randomly selected member of the population. But if the testimony holds up under cross examination and no such evidence is forthcoming, then the defendant's guilt will be normically supported, and the normic account will not stand in the way of conviction ${ }^{17}$. It is

\footnotetext{
${ }^{16}$ Put differently, testimony in favour of a proposition $\mathrm{P}$ provides prima facie normic support for $\mathrm{P}$, which can be defeated either by evidence for one of the above narrative types, or by evidence against P. Epistemologists would conventionally describe evidence of the first kind as an 'undercutting' defeater, and evidence of the second kind as an 'overriding' defeater. It turns out that the underlying mechanisms of defeat are indeed different in each case. While the undercutting evidence removes the need for explanation in the event that $P$ is false, the overriding evidence introduces a need for explanation in the event that $\mathrm{P}$ is true. In either case we have the upshot that the falsity of $P$, in light of one's total evidence, may require no more explanation that its truth. I won't explore this further here - but see Smith (2016, sections 4.3 and 7.2 ) for further discussion of normic support and defeat.

${ }^{17}$ Di Bello draws a distinction between what he calls a partial identification - in which the evidence 'attests' that the defendant and the offender possess a particular trait - and a full identification - in which the evidence attests that the defendant is the offender (Di Bello, 2019, pp1276). While Di Bello acknowledges that there is a
} 
worth emphasising once again, though, that the normic account does not oblige jurors to accept such testimony, or to return a guilty verdict on its basis - this will be a matter for their discretion, or may even be subject to further rules and requirements. A number of theorists have argued that a criminal conviction should not be based upon a single eyewitness identification of this kind (see, for instance, Sangero and Halpert, 2007, section VI, Thompson, 2008) - and the normic account is in no tension with such a stance ${ }^{18}$.

If the normic account is correct, then criminal convictions should not be based solely on cold-hit DNA evidence, cold-hit fingerprint evidence or on a template description of an offender's appearance, no matter how specific it is. Such consequences should of course be taken into consideration when assessing the viability of the normic account - and could be treated as disadvantages that need to be weighed against whatever benefits the theory offers. But these positions on DNA, fingerprint and description evidence are not unprecedented - and have each been endorsed by others on independent grounds. One might describe the normic account as a 'revisionary' theory - and I have no deep-seated objection to this label - but it is better perhaps to see it as a theory that forces a stand on several contentious issues involving significant legal categories of evidence ${ }^{19}$.

\section{References}

Chalmers, J. (2014) 'Corroboration: Consequences and criticism' in Chalmers, J., Leverick, F. and Shaw, A. eds. Post-Corroboration Safeguards Review Report of the Academic Expert Group (Edinburgh: Scottish Government)

Cohen, L. (1977) The Probable and the Provable (Aldershot: Gregg Revivals)

significant epistemological difference between these two categories, he denies that an eyewitness identification could ever be full in this sense, since it couldn't be based upon 'unique characteristics that exclude everybody except the defendant' (Di Bello, 2019, pp1276-1277).

But what would it actually be for an eyewitness identification to be based on characteristics that 'exclude everyone except the defendant'? If this means that the identification is guaranteed to be correct, then of course no identification could meet this condition. But, as argued, from the fact that an eyewitness is fallible and could always be making a mistake, it doesn't follow that the identification is unable to provide normic support for a defendant's guilt. I would be inclined to say that eyewitness identifications - apart from the special category that I have set aside - should count as full identifications in line with Di Bello's definition. The evidence provided by an eyewitness identification does 'attest' that the defendant is the offender (but, obviously, doesn't make this conclusion certain).

18 In some jurisdictions, there are explicit rules which prevent a conviction from being based upon a single eyewitness identification - such as the corroboration rule in Scotland or the unna testis nullius testis rule in the Netherlands (see Chalmers, 2014). While such rules can provide a valuable safeguard against convictions based upon unreliable eyewitness identifications, they are often criticised for treating all eyewitness identifications alike (see Loftus, 1996, pp188, Thompson, 2008, pp1541, Davidson and Ferguson, 2014, section (a)). The normic account is consistent with rules of this kind, but might also be used to motivate a more discriminating approach to eyewitness identifications.

19 I would like to thank Marcello Di Bello, Philip Ebert, Lewis Ross and two anonymous referees for very helpful comments on earlier versions of this paper. Work on this paper was supported by the Arts and Humanities Research Council (grant numbers AH/T002638/1 and AH/L009633/1). 
Cole, S. and M. Lynch (2006) 'The social and legal construction of suspects' Annual Review of Law and Social Science v2, pp39-60

Cullison, A. (1969) 'Probability analysis of judicial fact-finding' University of Toledo Law Review v1, pp538-598

Davidson, F. and P. Ferguson (2014) 'The corroboration requirement in Scottish criminal trials: Should it be retained for some forms of problematic evidence?' International Journal of Evidence and Proof, v18, pp1-27

Di Bello, M. (2019) 'Proof paradoxes and normic support: Socializing or relativizing?' Mind v129, pp1269-1285

Enoch, D., T. Fisher, and L. Spectre (2012) 'Statistical evidence, sensitivity and the legal value of knowledge' Philosophy and Public Affairs v40, pp197-224

Enoch, D. and T. Fisher (2015) 'Sense and "sensitivity": Epistemic and instrumental approaches to statistical evidence', Stanford Law Review, v67, pp557-611

Evett, I. and R. Williams (2015) 'A review of the sixteen point fingerprint standard in England and Wales' Journal of Forensic Identification v65, pp557-580

Gardiner, G. (2019) 'The reasonable and the relevant: Legal standards of proof' Philosophy and Public Affairs v47, pp288-318

Hedden, B. and M. Colyvan (2019) 'Legal probabilism: A qualified defence' Journal of Political Philosophy v27, pp448-468

Hinchman, E. (2005) 'Telling as inviting to trust' Philosophy and Phenomenological Research v70, pp562-587

Koehler, J., A. Chia and S. Lindsey (1995) 'The random match probability in DNA evidence: Irrelevant and prejudicial?' Jurimetrics v35, pp201-219

Krauss, S. (forthcoming) 'Against the alleged insufficiency of statistical evidence' Florida State University Law Review

Laudan, L. (2006) Truth, Error and the Criminal Law (Cambridge: Cambridge University Press)

Levanon, L. (2019) 'Statistical evidence, assertions and responsibility' Modern Law Review v82, pp269-292

Littlejohn, C. (2020) 'Truth, knowledge and the standard of proof in criminal law' Synthese v197, pp5253-5286

Loftus, E. (1996) Eyewitness Testimony (Cambridge, MA: Harvard University Press)

Marušić, B. (2015) Evidence and Agency: Norms of Belieffor Promising and Resolving (Oxford: Oxford University Press)

McCartney, C. (2006) Forensic Identification and Criminal Justice (Cullompton: Willan Publishing) 
McCauliff, C. (1982) 'Burdens of Proof: Degrees of belief, quanta of evidence or constitutional guarantees?’ Vanderbilt Law Review v35, pp1293-1335

Moran, R. (2018) The Exchange of Words: Speech, Testimony and Intersubjectivity (Oxford: Oxford University Press)

Moss, S. (forthcoming) 'Knowledge and legal proof' Oxford Studies in Epistemology v7 (Oxford: Oxford University Press)

Nance, D. (2016) The Burdens of Proof (Cambridge: Cambridge University Press)

Nesson, C. (1979) 'Reasonable doubt and permissive inferences: The value of complexity' Harvard Law Review v92, pp1187-1225

Redmayne, M. (1998) 'The DNA database: Civil liberty and evidentiary issues' Criminal Law Review, July, pp437-454

Roth, A. (2010) 'Safety in numbers? Deciding when DNA alone is enough to convict' New York University Law Review v85, pp1130-1185

Saks, M. and J. Koehler (2005) 'The coming paradigm shift in forensic identification science' Science v309, pp892-895

Sangero, B. and M. Halpert (2007) 'Why a conviction should not be based on a single piece of evidence: A proposal for reform' Jurimetrics v48, pp43-94

Shauer, F. and R. Zeckhauser (1996) 'On the degree of confidence for adverse decisions' Journal of Legal Studies v25, pp27-52

Smith, M. (2016) Between Probability and Certainty: What Justifies Belief (Oxford: Oxford University Press)

Smith, M. (2018) 'When does evidence suffice for conviction?' Mind v127, pp1193-1218

Stein, A. (2005) Foundations of Evidence Law (Oxford: Oxford University Press)

Thomson, J. (1986) 'Liability and individualized evidence' Law and Contemporary Problems v49, pp199-219

Thompson, S. (2008) 'Beyond a reasonable doubt? Reconsidering uncorroborated eyewitness testimony' University of California Davis Law Review v41, pp1487-1545

Tribe, L. (1971) 'Trial by mathematics: Precision and ritual in the legal process' Harvard Law Review v84, pp1329-1393

Wells, G., M. Small, S. Penrod, R. Malpas, S. Fulero, C. Brimacombe (1998) 'Eyewitness identification procedures: Recommendations for lineups and photospreads' Law and Human Behaviour v22, pp603-647 